\title{
Networking Strategies For Professional Women
}

Robert L. McGinty, (Email: drsmcginty@msn.com), Eastern Washington University

\begin{abstract}
This article deals with the concept of networking as one means of obtaining positions of power with the ability to influence others. A strategy of networking is discussed for individuals seeking advancement in their careers, with a primary focus on women, so that they may position themselves to realize their potential as managers expeditiously through their day to day job performance or obliquely through out their careers. The results of a field survey of successful networking strategies for career women are discussed.
\end{abstract}

\section{NETWORKING STRATEGIES FOR WOMEN}

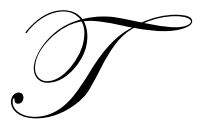

he focus of this article was conceptualized with women readers as the primary audience because it has long since been my belief that they face multiple challenges in the male dominated world of business. I often hope that I am wrong; that my belief about what equal opportunity ought to be is met by reality. I'll let you be the final judge of that and simply share my thoughts as I visualize the current status of women and how they might improve upon it.

As members of a protected class under equal employment laws and regulations, women must be given equal opportunity in the work place. While disparate treatment is carefully monitored and occurs infrequently, a more discrete type of discrimination known as disparate impact pinpoints the plight of women in the workplace. Disparate treatment occurs when protected class members are treated differently from others while disparate impact occurs when there is a substantial under-representation of protected class members as a result of employment related decisions that work to their disadvantage. The former is commonly known as Type I discrimination and the latter is Type II discrimination. Both are illegal under various existing state \& federal laws and regulations. While women outnumber men in the workplace, only a small percentage makes it to the upper echelons of organizations.

One of the fastest developing trends in industry the past several decades has been the increase in women gainfully employed in the work place. Of interest, then, is how women succeed when compared to other groups. Women outnumber men in the work force yet make about $71 \%$ of what their male counterparts earn. (Blau, 1986) This has been justified in the past based on differences in education or years of experience. However, when education and experience are controlled during analysis of earnings, women still earn $16 \%$ less than men for the same work. Perhaps, this difference in achieving success depends more on personal career strategies rather than overt or covert discrimination. Specifically, perhaps men tend to network for success while women form friendships through networking. Smeltzer writes, "Strong network ties have traditionally been perceived as a means of obtaining power that is seen as critical to a manager's success. (And) as a result, frequent reference is made to the 'Old Boys' Network'." (Smeltzer, 1989)

Women have not been compensated at the same levels as their male counterparts. This fact seems to suggest that women may not have achieved equal results due to unequal opportunity. What undercurrents run against the growing tide of women aspiring to become CEO's, holding them at bay as they bump into the Glass Ceiling? Perhaps, this disparate impact is due to some covert form of discrimination. 
Yet, discrimination either directly or indirectly may not be the primary cause of women being unequally represented in, or compensated for, top managerial positions. Perhaps, the reason fewer women realize successful careers lies elsewhere? For example, women may not have gained sufficient support from those powerful individuals or groups that make or influence these two important employment related decisions. Hence, women may not be visible enough for consideration as hiring and compensation decisions are being made. Networking would appear to be one possible avenue that women might pursue in order to gain this visibility and obtain the necessary support of individuals and groups making the decisions. Are women effective and efficient networkers?

As individuals, professional career women in the field of business are faced with many challenges that are both exciting and difficult. Yet, individuals within this segment of our population cannot rely on group success per se; they must constantly be working to insure their own accomplishments. Each individual must develop a personal career strategy that will enable them to develop contacts with others and formulate relationships of trust with influential people or groups that can help them succeed in their respective fields. Effective networking is one means of doing this. An individual's sphere of influence might include support groups, sponsors or mentors to help ease the transition up the organizational ladder. "Sponsors and mentors (provide) tutelage, advice, inspiration and influence in the organization." (Morrison, 1990) This influence encompasses daily performance on the job as well as positioning oneself for advancement either in-house or with another organization. In short, to succeed any manager must meet performance expectations and be considered as a leading candidate for advancement to a more challenging position. Good performance is a necessary, but not sufficient, condition for advancement. In addition to good performance, a successful manager must be recognized by a broad network of associates as one of their own-a member of the fast track where members help one another to step through the barriers, represented by the Glass Ceiling, that women face.

According to Morrison, successful executive women make effective use of networks (1990). Yet, it is common fact that there are far more successful men residing in executive suites versus women. Perhaps, many women are unwilling or uninformed about how to network. Heim wrote, "The majority of women in the business world today are oblivious to the fact that they are standing on a playing field while a game is being played around them. Until (they) realize that business is conducted as a sport, (they'll) never move ahead and never win (1992)."

Surely, many women possess the same requisite capabilities to perform managerial jobs as men! The fact that they are not given the opportunity suggests that women do not network effectively since networking is regarded by many as a major means of obtaining employment; for example, see almost any national job placement statistics which show that a high percentage of jobs are found by networking.

Kotter writes, "The people judged most effective on the job were the people with the largest social networks (1982)." Since far more men are successful than women it seems to follow that men are more effective at networking. That is not to say, however, that women fail to make the attempts required to establish networks. What it does mean is that women are simply not as successful as men. As Smeltzer noted, "If the purpose of these (women) networks were instrumental rather than social, women in men-dominated environments might obtain a greater variety of information if they networked with some men rather than all women (1989)." In short, women network with other women and not with men. Men are the present power brokers.

To counter this situation, women must develop networking connections and turn them into mentor relationships where the combined influences of individuals can be utilized both to open avenues of opportunity and to help facilitate performance on the job. In a real sense then, it is not only important that women possess the requisite skills and knowledge of their profession, that is, knowing what needs to be done, they must also know the right people in order to accomplish what needs to be done on a daily basis. That is, they must know how to get their work done. And, here I refer to the how aspect of work as a set of action plans; especially those designed to over come resistance and facilitate acceptance. Acceptance by the power brokers, and being empowered by them through their support, is vitally important. 
This acceptance will first necessitate becoming known, according to Pat Heim's who writes (1992):

If you're unknown, all the hard work in the world won't get you where you want to go . . 80 percent of getting the opportunity is being known. Consequently, you should make yourself known to the people who can control or impact your career: managers, vice presidents, the corporation's president or CEO.

Sometimes it's also useful to become acquainted with those who may not have much official power but actually wield great influence within the organization, like the president's secretary or the CEO's nephew over in marketing.

These inter-personal connections are the beginning of your personal network providing you avenues of information about your organization. However, don't make the common mistake committed by most women who spend most of their time connecting with other women. As Heim states, "research has shown that men are central to the dominant coalition in which promotion and pay decisions are made, (yet) women tend to network with women and men with men (1992)." In a real sense, then, those targeted for inclusion within your personal network(s) might include superiors as well as subordinates, people inside and outside the organization, peers, and individuals within the organization known to be on the fast track and thus well informed, secretaries, receptionists and others with access to information. Additionally, be a volunteer and a joiner. Volunteer for extra assignments where you have an opportunity to help another person resolve a problem. Adding to your list of interactions with others through membership in various in-house or external organizations and committees increases your sources of information. Collectively, these personal contacts will supply you with bits and pieces of information enabling you to put together the big picture of events taking shape at work. In a sense, successful networkers are also pretty good detectives. They investigate and do research on what is taking place within their organization. It requires stepping aside from the daily routine of events and viewing the synergistic happenings at work. You need to visualize the Big Picture, seeing the forest as well as the individual trees.

Or, viewed another way, networking consists of engaging in socio-economic activities that will help you to develop opportunities for interacting with others in order to stay informed, and to provide yourself with an opportunity to display your talents so that you will be viewed as a central player within the organization. The main point to remember here is that you want to position yourself so that you can receive and exchange useful information. How you manage this information network is central to your effectiveness and to your success.

Women have made tremendous progress over the last few decades. They are moving into management positions in greater numbers than ever before; however, they still have a long way to go. If a woman wants to succeed in business as a manager, she must engage in a specified set of activities, activities identified by Luthans as those used by real managers aspiring to be both successful and effective (1988). How well women perform these various activities is prerequisite to how successful they will be in their careers.

Luthan's four activities, engaged in by "real managers," include (1) networking, (2) communicating, (3) human resource management and (4) traditional management practices. The first two are tied closely together and are instrumental in developing specific career strategies leading to success for those able and willing to put the theories into practice. They are rudimentary elements of any 'how-to' plan of action. For example, Luthans defined success in terms of promotion and noted that managers receiving promotions spent a large proportion of their time networking and communicating. The latter two sets of Luthan's cluster of activities deal with the requisite duties or knowledge about a managers job, namely, what must be done; and, to some extent the on going work related behavior dealing with how to accomplish what it is that must be done. Yet, a more important element of accomplishing specific duties is influencing others to follow your directives, thus working on your behalf. It is this element of work, i.e., making connections and thus acquiring the capability to influence others to cooperate, which is the primary justification for networking. Your communication skills coupled with an understanding of human resources will enable you to network resulting in your being more effective in carrying out the daily practice of management. 
The set of activities that Luthan's refers to as "communicating" includes people or interpersonal skills. They are important for effective networking. Of prime importance is the personal dialogue that takes place, a form of communicating that Baber refers to as "small talk (which) turns networking contacts into Great Connections (1988)."

Allan Koltin and Sandra Grant Carcione write about networking as "staying current on industry information and advancing your firm's business development goals by cultivating people contacts (1990)." Of course, it means much more than this to the individual since the personal contacts they make can be extremely valuable in furthering one's own career as well. Networking is making and using personal contacts that further one's personal and career goals.

Enhancements of networking include cutting through red tape when carrying out difficult intra-organizational assignments especially when pressed for time, initiating contacts with another organization (inter-organizational networking), keeping abreast of cutting edge business practices, or staying informed about various employment opportunities in the business community. Such opportunities might be cultivated for the organization or one's own benefit, or for the benefit of another member of an individual's networking group(s). Such liaison work is fast becoming a norm in manufacturing as companies form joint venture teams composed of manufacturing representative, suppliers and customers who come together to develop high tech products within an ever decreasing time frame.

In another sense, networking also affords the insightful individual a potential opportunity to play musical chairs, that is, to move into an improved job/career position within your present firm or at another firm. Just as important, however, it enables you to meet individuals on a professional, personal or social level. Who you know, then, becomes as important as what you know. Most individuals do not possess great power; however, many people have sufficient contacts that they are able to influence and use the collective powers of others. The manner through which they do this captures the primary essence of networking.

The fundamental key to successful networking involves meeting as many people as possible, people from all walks of life. These individuals are themselves members of networks and can introduce you to their members. If you ask your contacts to introduce you to their contacts, you have an opportunity to greatly increase your own visibility. Be prepared to return the favor, of course. This give and take will culminate in an ever increasing network of friends, mentors and valuable liaisons that will be able to assist you in a number of important ways: professionally, personally, or socially. It requires becoming an active member of the team.

According to Heim, "Men show allegiance to the team by networking and helping others in the network, (but) you can't wait until the opportunity arises to network with someone. You might never come across the crucial person or opportunity (in time) if you do. Sometimes you have to create the situation yourself (1992)." In other words, you may need several mentors, influential people who can help you figure out a game plan for advancing your career or assist you in overcoming daily obstacles. And, you will need to establish these contacts before a crisis arises.

So what should you do to position yourself? First, decide which accomplishments or goals you want to communicate or accomplish. Then find ways to convey your successes directly or indirectly to the people you've determined need to hear about them and who are in a position to influence the outcomes. For examples, Heim suggests submitting weekly reports to your superiors (written or verbal), asking colleagues for feedback on a project in order to let them know how successfully it's going, making sure your projects get mentioned in the company newsletter, involving the power brokers in projects and committees you're working on, or at least keeping them updated, befriending members of the public relations department, and attending trade conferences.

You may have to take a small risk and go outside your comfort zone by volunteering to speak at a conference, to serve on cross-departmental committees, or to work, for example, with the United Way campaign. And, be sure to attend company sponsored social functions such as the company picnic, softball games and Christmas party. In other words, as Heim succinctly states, "Let your superiors know you have a brain (because) by connecting with others, you not only let them know about your qualifications, you also develop great channels for receiving information about your organization" (1992). 
An important aspect of networking is to identify the kinds of organizations within which you what to establish contacts. So, make a list; for example, political, professional or community service organizations. Then, for each type of organization identify a specific organization in your community such as a major civic organization, a political or professional group and so forth. Next, do your homework and learn everything you can about the firm and those individuals you wish to meet. I strongly recommend that you keep a little black book listing the contacts you already have, you may wish to use one color of ink, say black, for this group. Then, using another color of ink, list the individuals by type of organization that you would like to meet. Perhaps, you may elect to use red ink for this group; then, a quick glance at your black book listing one specific organization, you can readily identify the people you know (listed in black) and the people you expect to know in the future (listed in red). These are the people who can help you discover new solutions to business problems that you will use on your present job. Or, they can help keep you aware of new job opportunities if that becomes a necessity during this decade of restructuring and downsizing.

In keeping with the above examples as a source of individuals with which to network, remember that business or professional directories list individuals and their position within given organizations. These directories are available through your local library, Better Business Bureau or Chamber of Commerce. Think of these listings as a cast of characters in a play where the plot is your career. How will each help or hinder your progress from present job to succeeding jobs that offer more challenge, more opportunity, more rewards? Who is available for consultation should you be assigned a difficult project requiring a wide variety of expertise? Who might write you that all important letter of recommendation for a promotion? The opportunities for meeting people and obtaining their support are many and varied, limited only by your imagination. For example, the Society of Human Resource Management maintains a 'hotline' for members that connects individuals with other professionals willing and able to assist in handling complex issues such as sexual harassment or developing cost effective ways to meet a multitude of legal compliances required by state or federal law. Many electronic bulletin boards exist that may also be used in this fashion.

The public library is also a good place to start learning about organizations and the people who run them. Obtain news clippings of individuals and official rosters of employees using business directories available at the local libraries, small business centers and local area economic development centers. For example, The Spokane Business Directory is an excellent source book for identifying organizations and the top managers who run them. Additionally, 10-k reports list top administrators of publicly held corporations.

Finally, prepare a list of networking goals: sales contacts, job interviewing opportunities, social or professional contacts. Hold yourself accountable for reaching these goals, be bold and take a few risks. Taking "calculated risks" when meeting people allows you to step outside of your normal comfort zones (Baber, 1976). You'll soon become comfortable doing this and you will be amazed how easy it can be to gain an introduction to a preselected individual working for a specific type of organization. Then, when you need help reaching some particular objective, follow the advice of Jack Cannfield, "If you want to G.E.T., you must A.S.K." That is, to get something you have to ask for it! Again, be prepared to return the favor; after all, that is what successful networking is all about.

Join as many organizations as you can and attend important gatherings as time and work schedules permit. Meet as many important people as you can because business people tend to hire and do business with people they know rather than strangers. Don't be a stranger!

Networking is easier said, than done; yet, what you say is extremely important. Interpersonal skills are an important aspect of effective networking. Baber writes, "To make real and lasting connections with people, you must develop one of today's most important interpersonal skills-the ability to enjoy, engage, exchange, and explore through small talk ... to make connections with people who have information and other resources that will benefit you in your work (1991)."

You must develop a passion for it and become a self starter. This means that you must want to become a good networker and have the interpersonal skills to be good at networking. In other words, you must know how to cope with people so that you can interact with them. Activities essential for making connections during the course of 
networking include mingling with others, striking up conversations, remembering people's names and positions, and having something to share. Baber believes that "the number one business skill . . . is the ability to communicate a message to strangers (1991)."

This means that you may have to expand your comfort zone, sharpen your communication skills and engage in productive socializing to enhance your performance and career success. According to Baber, "often there's no clear line between social (or business) occasions and networking. People who get ahead in business create connections deliberately and professionally (by) engaging in small talk (1991) ${ }^{1}$."

Small talk is a process of interacting with people using verbal or non-verbal communication to establish trust or to exchange ideas and information. In other words, you must get the most out of your interactions with others. The time spent interacting with associates and people you encounter during the course of your daily business routine might be viewed as a type of personal investment one makes for the sake of her career.

According to Baber, "skillful small talkers see people as walking encyclopedias, how-to-books, and personalized Yellow Pages (1991)." These individuals know the complexities of influencing others as part and parcel of goal achievement. The key point to remember here is that engaging people in 'small talk' presents numerous possibilities for the person searching for networking opportunities ranging from cocktail conversation, relaying or obtaining information at work, or forming a professional relationship that may prove valuable in the future while attending a business convention or professional conference.

If it's true that other people look into our minds when we open our mouths to speak, then having something to say or talk about , i.e., having an agenda, makes a great deal of sense. Therefore, as preparation for ensuing small talk, prepare lists of information or ideas to exchange in order to explore future business possibilities. In a real sense, preparing an agenda is akin to doing homework prior to attending a review session for a forthcoming exam. You want to list what you know and what you don't understand. Then, you have certain things you look for and need to learn while having something to exchange or give back to the others in attendance. Networking involves giving as well as receiving.

According to Baber, "managing small talk situations is quite different from manipulating other people in small talk situations. Managing is okay; manipulating is not ... effective small talk and satisfying connections are based on saying who you are and what you want." This doesn't mean that you need to lay all your cards on the table or treat conversations as a confessional, rather, it implies being open and up-front with people. Again, remember Jack Cannfield's advice, "if you want to G.E.T. you must A.S.K.!" And, in keeping with a give and take balance during any exchange with someone, you should remember the concept of dual consideration; that is, each party to the conversation will give and receive approximate equal value in terms of information.

Baber advises against flirting, "It has no place in business (1991)." But do be yourself and show up at events, meetings, and conferences where the opportunities for meeting people exist. If you stay current in your field and about world news and events, you will have a store of information to share, discuss, defend, support. Thus, you'll be well prepared to engage others and form new networks. Baber writes, "When you know how to small talk, networking can be used to: demonstrate your skills and expertise, learn new skills, job hunt, change careers, cope with change, grow personally and professionally, find new resources, discover new directions, get feedback about yourself and your activities, create opportunities for yourself, and meet people for any reason you might have (1991)." This means meeting people within your organization that you work with as well as meeting people outside of the organization such as actual or potential suppliers or customers.

\footnotetext{
${ }^{1}$ For learning specific techniques on establishing rapport with individuals as part of networking, see Baber, Ann \& Lynne Waymon, Great Connections: Small Talk and Networking for Business people, Impact Publications, 1991, and Raye-Johnson Venda, Effective Networking: Proven Techniques for Career Success, Crisp Publications, Inc., 1990.
} 
It is extremely important to know people and to stay in touch because you never know when you will need their help or support, or, when someone will need your assistance. In a real sense, you are promoting yourself so you want to associate with others who can help you. As Baber writes, "plan to associate with people who can help you think of new ideas, new ways of doing things (because) a mind that feeds only on itself is undernourished (1991)."

\section{SURVEY RESULTS}

To check the networking experiences of women, a convenience sample of 33 women were contacted and interviewed using a structured questionnaire. The questions and recorded responses may be of interest to other women as they reflect on their own networking experiences.

1. Do you actively network for specific purposes such as job openings, sales contacts, research, other?

Nearly $70 \%$ of the women responded that they do network, but a majority of these do so primarily with other women.

2. What are some examples of networking tactics that worked for you?

Membership on committees was the leading response followed by attending a church, receptions, symphonies. Several mentioned "staying in touch with your peers using the grapevine."

3. Do you keep a written record of your networks?

Only one individual kept any sort of record, her response to the question was, "No, well I use my calendar." Hopefully she keeps the old calendars for future use.

4. What advice would you offer to inexperienced networkers?

"Make sure you have something to offer ... ask questions."

"Meet as many people as possible, not as foes, but as friends."

"Don't be shy when you meet people."

"Make sure people understand what you are doing."

"Listening skills are important."

"Be open to new information."

"Be open, friendly and as extroverted as possible."

"Play bridge, take a training course, attend workshops such as Dale Carnegie, Toastmasters/Toastmistress."

"Maintain routine contact."

"Volunteer for difficult tasks."

"Get together for lunch."

"Bring a box of doughnuts to work or to give to a group that has helped you such as the shipping department."

5. How did you get your first job?

Without exception the responses clearly indicated that "I knew somebody who knew somebody else."

Many of the above comments are summarized by Luthans, who believes, "networking is a set of complex interpersonal activities that includes socializing and politicking such as non-work related chit chat; informal joking around with peers, friends, mentors, least preferred co-workers and those you admire; discussing rumors, complaining, griping, downgrading, gamesmanship; and interacting with outsiders such as customers, suppliers, vendors, public 
relations, external meetings, and community service." As such, networking is viewed as a system of relationships between and among collaborating individuals with connections and influence. It is a series of connections with people who can help you, or be helped by you, in almost any work related or non-work related aspect of life. Networking is that set of activities that result in establishing liaisons with individuals who can further one's personal and career goals. As such it is the linking of ideas and resources through people having shared values and interests. It can be horizontal, vertical, or diagonal in direction within or outside of an organization.

These liaisons provide individuals with an opportunity to stay informed using the information available through the contacts they make as they enlarge their network(s). It also provides you ample opportunities to display your accomplishments or to request that you be given the opportunity to face more challenges. Being visible is very important. For example, you might take the initiative to write weekly or monthly reports for your boss and ask subordinates, peers and your boss for feedback. Simple math suggests that four or five additional people will become better informed of your contributions using this approach to maintain visibility within the organization.

Or, you might take advantage of the suggestion box, company newsletter or bulletin board as outlets for your mini reports to keep others informed. Be a team player and do a little bragging about your company at trade shows, professional meetings or with influential members of your community. It is trite but true that "what goes around comes around," so make sure that good things about you and your organization are put into the diverse pipelines of information within and between your network(s) and their members. Heims put it this way, "it's ... important to note that an ambitious woman should never believe-not even for a second-that her performance will win her (a) position. She's got to talk her way into it (1992)." The speaking platform takes many forms, for example, volunteering to make a presentation at the annual company meeting or at a professional conference, asking to be a member of standing or ad hoc committees, helping raise money for charitable organizations, or simply attending professional and social gatherings such as meetings, trade shows, company social functions, coffee breaks, luncheons and the like.

At work, plugging into the organizational grapevine is a necessary evil from one perspective and an angelic opportunity from another. But regardless of how it is viewed, information from your network(s) is vital to your job and career success. Such information helps enable you to be an effective manager, and to achieve promotions and financial rewards.

Remember the words of Alan McGinnis, who wrote, "There is a soft-headed type of thinking that masquerades as optimism, but it is quite different from the practical approach that brings success (1987)." The practical approach to success through networking is to network with individuals for the sole purpose of helping you help yourself. Keep in mind the members of your network(s) that can help you through out your career instead of merely meeting people to have someone to talk with on a social basis. While social contacts are important, they are only one of several types of contacts gained through networking.

Also, remember four basic steps when building a networking strategy. First, decide what your vision quest or future career aspirations are; second, develop a list of organizations and individuals that are in a position to help you achieve your goals; third, initiate contact, develop rapport, establish ties, ask for assistance, be willing to give of yourself in return; and fourth, devote time to establishing and maintaining your network(s).

The challenge faced by aspiring networker is to identify what she wants, find the person who can help, meet her (or him), and then ask for help. I think you will be pleasantly surprised at how pleased individuals will be that you care enough about them to ask for their assistance. And, you can count on reciprocating when the time comes for them to come to you for advice and counsel. When that happens, you'll know for sure that you are well on your way to achieving success. Remember, you are not competing against men or other women for promotions and advancement. You are competing with them. Therefore, you must engage in the same set of networking activities that they do in order to enhance your own chances for success. Become visible, work hard and position yourself to assist others in helping you succeed. Networking is one means of doing this. 


\section{REFERENCES}

1. Baber, Anne \& Lynne Waymon, Great Connections: Small Talk and Networking for Business people, Impact Publications, 1991.

2. Luthans, Fred, et al, Real Managers, Cambridge: Ballinger Publishing Company, 1988.

3. Koltin, All \& Sandra Grant Carcione, The Basics of Networking, New Accountant, April 1990.

4. $\quad$ Baer, Joan, How To Be An Assertive Woman, New American Library, 1976.

5. $\quad$ McGinnis, Alan Loy, The Power of Optimism, Harper \& Row, 1987.

6. Blau, Francine, \& Berber, Marianne A. The Economics of Women, Men, and Work. Englewood Cliffs, N.M.: Prentice Hall, 1986.

7. Heim, Pat with Susan K. Golant, Hardball for Women: Winning at the Game of Business, RGA Publishing Group, Inc., Los Angeles, 1992.

8. Kotter, J. P., The General Managers, The Free Press, 1982.

9. Morrison, Ann M., et al, Breaking the Glass Ceiling: Can Women Reach the Top of America's Largest Corporations?, The Manager's Bookshelf, Jon L. Pierce \& John W. Newstrom (ed., 2nd), Harper \& Row Publishers, New York, 1990.

10. Raye-Johnson, Venda, Effective Networking: Proven Techniques for Career Success, Crisp Publications, Inc., 1990.

11. Smeltzer, Larry R. \& Gail L. Fann, Gender Differences in External Networks of Small Business Owner/Managers, Journal of Small Business Management, Vol. 27, No. 2, April 1989.

\section{NOTES}




\section{NOTES}

